\title{
A child with raccoon roundworm meningoencephalitis: A pathogen emerging in your own backyard?
}

\author{
Jan Hajek $M D^{1,2}$, Yvonne Yau MD³ , Peter Kertes $M D^{4}$, Teesta Soman $M D^{5}$, Suzanne Laughlin $M D^{6}$, Ronik Kanani $M D^{7}$, \\ Kevin Kazacos DVM PhD ${ }^{8}$, Sriveny Dangoudoubiyam $\mathrm{MS}^{8}$, Mary Anne Opavsky MD PhD ${ }^{1}$
}

J Hajek, Y Yau, P Kertes, et al. A child with raccoon roundworm meningoencephalitis: A pathogen emerging in your own backyard? Can J Infect Dis Med Microbiol 2009;20(4):e177-e180.

Raccoon roundworm (Baylisascaris procyonis) is a cause of devastating neural and ocular disease. The first documented case of raccoon roundworm encephalitis in Canada, in a seven-year-old boy who presented with severe neurological impairment, is presented. His significant recovery illustrates the importance of clinical suspicion and the benefit of early treatment.

Key Words: Baylisascaris procyonis; Encephalitis; Eosinophilia; Larva migrans; Meningitis

\section{Un enfant atteint d'une méningoencéphalite par nématode du raton laveur : Un pathogène émergent dans votre cour?}

\begin{abstract}
Le nématode du raton laveur (Baylisascaris procyonis) est une cause de maladie neurale et oculaire dévastatrice. Les auteurs présentent le premier cas documenté d'encéphalite par nématode du raton laveur au Canada, chez un garçon de sept ans souffrant d'une grave atteinte neurologique. Son rétablissement notable démontre l'importance de la présomption clinique et les bienfaits d'un traitement rapide.
\end{abstract}

$\mathrm{R}$ accoons are common in North America, and often live in close proximity to people, particularly in cities such as Toronto, Ontario, where their density reaches over 100 raccoons per square kilometre (1). Approximately 50\% of raccoons in Ontario carry the roundworm Baylisascaris procyonis asymptomatically in their intestinal tract and shed millions of eggs in their stool $(2,3)$. These eggs are extremely resistant to disinfection and remain infective in the environment for years. If eggs are accidentally ingested by a human, or another susceptible host, larval infection can lead to devastating neurological disease and death $(2,4)$. We describe the clinical presentation of a Canadian child with $B$ procyonis meningoencephalitis and ocular larva migrans. The case is noteworthy in demonstrating neurological improvement in association with early administration of albendazole and corticosteroids.

\section{CASE PRESENTATION}

A previously healthy, active and communicative seven-yearold boy with autism presented to hospital in Toronto with lethargy and anorexia. His symptoms began insidiously two weeks before admission. Two days before admission, when the patient was seen in the emergency department, he was drowsy, but easily arousable. A marked peripheral eosinophilia (white cell count $11.6 \times 10^{9} / \mathrm{L}$; eosinophils $2.78 \times 10^{9} / \mathrm{L}$ ) was the only laboratory abnormality identified. He was treated for dehydration and discharged home. The following day, he returned to hospital with increasing lethargy and was refusing anything by mouth. He was incontinent of urine and appeared to have abdominal pain. He had no fever, headache, convulsions or rash. His Glasgow Coma Scale score was 8 (eyes $=3$, verbal $=2$, motor $=3$ ). He exhibited decorticate posturing, hyperreflexia, up-going plantar reflexes bilaterally, and a right gaze preference. He had no meningismus or fever. The peripheral eosinophilia had increased (eosinophils $4.23 \times 10^{9} / \mathrm{L}$ ). Cerebrospinal fluid (CSF) analysis revealed a white blood cell count of $22 \times 10^{9} / \mathrm{L}$ with $30 \%$ eosinophils. The CSF protein and glucose levels were normal. Magnetic resonance imaging (MRI) of the brain demonstrated abnormal enhancement in the cortex and cerebellum (Figure 1). Fundoscopy revealed small bilateral subretinal infiltrates, more prominent in the left eye (Figure 2).

There was no history of recent travel outside the country, and the child had no pets. However, the parents reported the presence of raccoons and raccoon latrines in their backyard. The child often played in an open sandbox in the backyard and had a habit of putting his hands in his mouth.

Given a strong suspicion of $B$ procyonis infection, albendazole $25 \mathrm{mg} / \mathrm{kg} /$ day and methylprednisone $30 \mathrm{mg} / \mathrm{kg} /$ day were initiated within $48 \mathrm{~h}$ of presentation. B procyonis ELISA was strongly positive in both serum and CSF (Table 1). The convalescent CSF titre increased fourfold (Table 1). The patient's serum was also positive by Western blotting and strongly positive in a recombinant antigen ELISA for $B$ procyonis, confirming the diagnosis. Toxocara serology was negative and Ascaris serology was indeterminate. A field investigation revealed two latrines with raccoon excrement in the child's backyard. Fecal samples from these latrines and soil from the sandbox contained B procyonis eggs.

${ }^{1}$ Division of Infectious Diseases; ${ }^{2}$ Department of Medicine, North York General Hospital; ${ }^{3}$ Division of Microbiology, Department of Paediatric and Laboratory Medicine; ${ }^{4}$ Department of Ophthalmology; ${ }^{5}$ Division of Neurology; ${ }^{6}$ Department of Medical Imaging; ${ }^{7}$ Division of Paediatric Medicine, Department of Paediatrics, Hospital for Sick Children and the University of Toronto; ${ }^{8}$ Department of Comparative Pathobiology, Purdue University

Correspondence: Dr Jan Hajek, North York General Hospital, 4001 Leslie Street, GW-33, Toronto, Ontario M2K 1 E1.

E-mail jan.hajek@utoronto.ca 

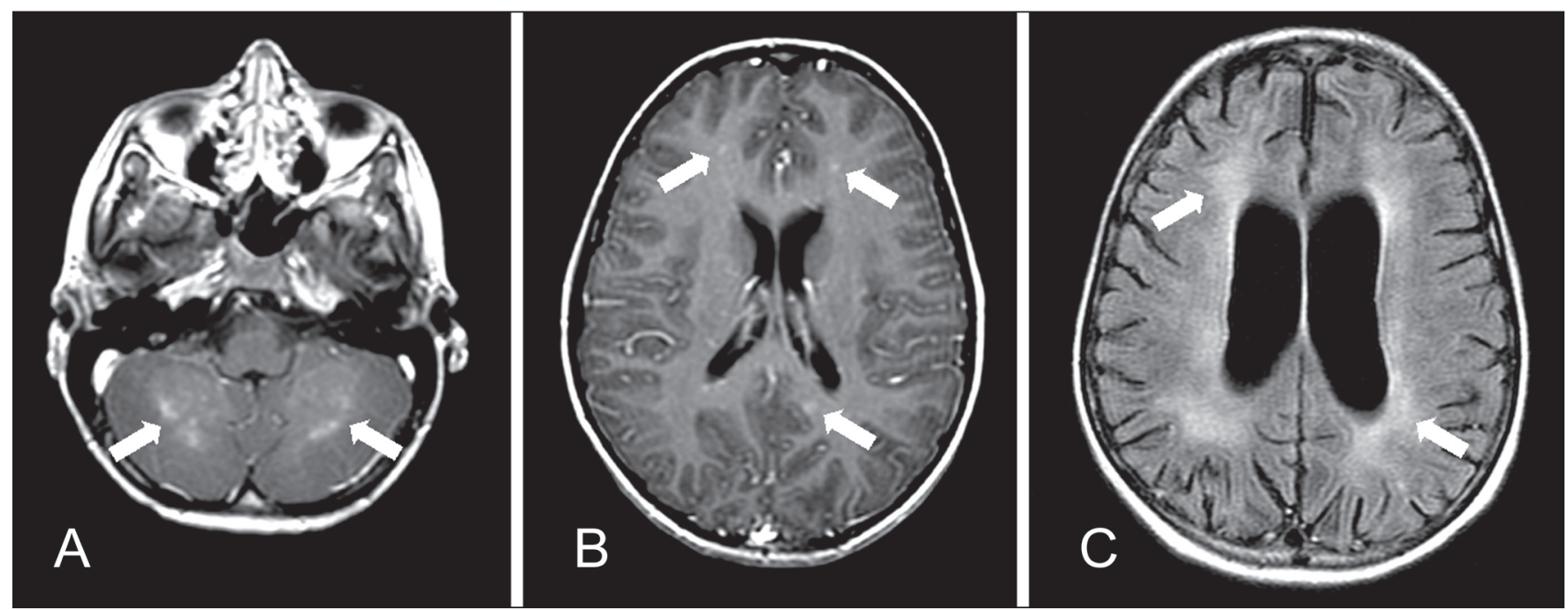

Figure 1) Magnetic resonance imaging of the brain of a seven-year-old boy with Baylisascaris procyonis eosinophilic meningoencephailitis. A Gadolinium-enhanced T1-weighted axial image at presentation, demonstrating patchy areas of abnormal enhancement of the cerebellar greywhite junction at presentation (arrows). B Axial T1-weighted image post-gadolinium, demonstrating small foci of nodular enhancement bilaterally in the cerebral cortex at presentation (arrows). C Fluid-attenuated inversion recovery (FLAIR) axial image three months following presentation demonstrating diffuse volume loss with prominent sulci and ventricular enlargement, and white matter gliosis (arrows). The previously noted nodular enhancement had resolved

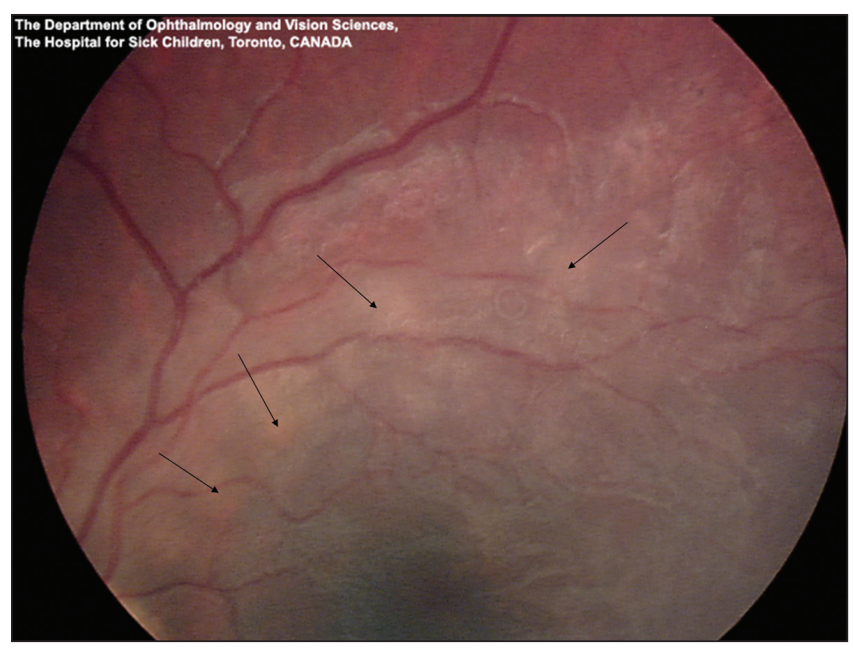

Figure 2) Fundus photograph of the left eye of a seven-year-old boy with Baylisascaris procyonis eosinophilic meningoencephalitis. Magnified view of the superotemporal arcade showing ill-defined creamy subretinal infiltrates with a subtle overlying retinitis and vasculitis (arrows)

The patient improved with treatment. Within days, he became more alert and his gaze deviation resolved. After five days, methylprednisone was changed to oral prednisone $2.5 \mathrm{mg} / \mathrm{kg} /$ day. By one month, he was able to tolerate oral nutrition and weight bear with assistance. The eosinophil count had normalized. Albendazole was discontinued at that time, and prednisone was gradually tapered. At a four-month follow-up visit, the patient had made significant improvement, and was ambulatory and interactive. He regained his baseline level of function, with the exceptions that he no longer used speech to communicate, had cortical visual impairment and a seizure disorder. A repeat MRI documented postinflammatory atrophic changes, with no acute disease (Figure 1).
TABLE 1

Results of laboratory investigations

\begin{tabular}{|c|c|c|c|c|}
\hline Investigations & $\begin{array}{c}2 \text { days } \\
\text { before } \\
\text { admission }\end{array}$ & $\begin{array}{l}\text { On admis- } \\
\text { sion to } \\
\text { hospital }\end{array}$ & $\begin{array}{c}4 \\
\text { months } \\
\text { later }\end{array}$ & $\begin{array}{c}\text { Normal } \\
\text { range }\end{array}$ \\
\hline \multicolumn{5}{|l|}{ Complete blood count } \\
\hline White cell count $\left(\times 10^{9} / \mathrm{mL}\right)$ & 11.6 & 14.8 & 6 & $4.0-10.0$ \\
\hline Neutrophils $\left(\times 10^{9} / \mathrm{mL}\right)$ & 6.49 & 9.03 & 8.51 & $1.5-8.0$ \\
\hline Lymphocytes $\left(\times 10^{9} / \mathrm{mL}\right)$ & 2.21 & 2.22 & 0.79 & $1.7-7.0$ \\
\hline Monocytes $\left(\times 10^{9} / \mathrm{mL}\right)$ & 0.12 & 0.44 & 0.1 & $0.05-0.8$ \\
\hline Eosinophils $\left(\times 10^{9} / \mathrm{mL}\right)$ & 2.78 & 3.11 & 0.5 & $0.02-0.5$ \\
\hline Hemoglobin (g/dL) & 130 & 141 & 130 & $120-160$ \\
\hline Platelet count (per mL) & 253 & 263 & 265 & $150-400$ \\
\hline $\begin{array}{l}\text { Serum Baylisascaris } \\
\text { procyonis IgG (ELISA } \\
\text { optical density) }\end{array}$ & & 1.813 & & $<0.250$ \\
\hline \multicolumn{5}{|l|}{ CSF panel } \\
\hline White cell count $\left(\times 10^{6} / \mathrm{mL}\right)$ & & 22 & 7 & \\
\hline Neutrophils (\%) & & 0 & 0 & \\
\hline Lymphocytes (\%) & & 49 & 77 & \\
\hline Eosinophils (\%) & & 30 & 7 & \\
\hline Monocytes (\%) & & 21 & 16 & \\
\hline Red cell count $\left(\times 10^{6} / \mathrm{L}\right)$ & & 0 & 0 & \\
\hline Glucose (mmol/L) & & 3.9 & 3.2 & \\
\hline Protein $(g / L)$ & & 0.38 & 0.33 & $0.15-0.40$ \\
\hline $\begin{array}{l}\text { CSF B procyonis IgG (ELISA } \\
\text { optical density) }\end{array}$ & & 0.186 & 0.723 & \\
\hline
\end{tabular}

CSF Cerebrospinal fluid; IgG Immunoglobulin G

\section{DISCUSSION}

The present case illustrates the importance of early clinical suspicion of raccoon roundworm meningoencephalitis. Neurological improvement was observed in our patient following treatment with albendazole and corticosteroids. This patient's recovery from a coma to being independently mobile, communicative but nonverbal, and interactive was significant. 
Despite the remaining deficits, the outcome was significantly better when compared with most previously reported in the literature. Other patients with similar presentations have been characterized by more severe neurological sequelae or death (4). We speculate that early intervention with both albendazole and steroids may have contributed to this patient's partial recovery. Albendazole is active against migrating larvae of $B$ procyonis (2), while steroids may have a role in suppressing the host inflammatory response (4).

$B$ procyonis is being recognized with increasing frequency as a cause of human disease. There have been 14 reported cases of human infection (2,4-7), with over a dozen unpublished cases (Kazacos, personal communication). Most of the previously affected individuals were male and young or had developmental disabilities. Geophagia was a frequent risk factor. Initial clinical features may be subtle, with fever and meningismus frequently absent, but subsequent neurological deterioration is often dramatic (4-6). Approximately one-third of reported cases have been fatal, with the remainder having severe residual deficits including cognitive impairment, seizures, paralysis and blindness (4). The full spectrum of human disease is unknown but appears to range from subclinical infection to rapidly progressive disease $(4,5,7)$. Recently, a mild case of suspected $B$ procyonis infection was reported, with apparent early complete response after cerebellar edema was treated with early corticosteroids and later albendazole (7). Until an optimum therapeutic strategy is available, the principle of early treatment of this aggressive infection with both albendazole and steroids should be considered.

Ocular disease was reported in one-third of cases of $B$ procyonis meningoencephalitis (4). In our patient, fundoscopic examination revealed patchy bilateral subretinal infiltrates that resolved following therapy. Larval migration in the subretinal space can cause localized ocular damage leading to diffuse unilateral subacute neuroretinitis (8). Diffuse unilateral subacute neuroretinitis has been previously reported in Canada, and although rare, is important as a preventable cause of childhood blindness (9). Ocular larva migrans is most often unilateral; however, bilateral disease has been reported (10).

Eosinophilia is an important diagnostic clue of invasive helminthic infection. Although peripheral eosinophilia has a very broad differential diagnosis, eosinophilic meningitis has a much more limited differential diagnosis (11). In North America, infection with $B$ procyonis must be considered as a cause of eosinophilic meningitis and investigated (4-6). If a peripheral eosinophilia and/or CSF eosinophilia is found in a child with meningitis, in combination with risk factors such as young age, developmental delay and possible contact with raccoon feces, specific treatment and testing for $B$ procyonis of both serum and CSF should be initiated. In our patient, antibodies to $\mathrm{B}$ procyonis were detected and strongly positive in both serum and CSF (Table 1). The serum level was well above the putative cut-off value of the assay, and confirmatory testing was positive. $B$ procyonis serology is performed by ELISA from the Department of Comparative Pathobiology at Purdue University in West Lafayette, Indiana. ELISA for Baylisascaris antibodies uses larval excretory-secretory antigens and has a putative optical density cut-off value for serum of 0.250 or greater. CSF and ocular fluid should have no antibody present. Neuroimaging is nonspecific and may be normal initially. As seen in our patient, suggestive features on MRI include patchy periventricular and cerebellar white matter lesions accompanied by later atrophic changes $(4,5)$.

Ideally, homeowners, particularly those with children, should recognize the risk posed by raccoon feces and avoid raccoon latrines. However, we share our urban environment with raccoons, and avoiding all contact is not possible. An option when contact has been made with raccoon feces is postexposure prophylaxis with albendazole. In animal models it has been documented that the administration of albendazole shortly after ingestion of $B$ procyonis eggs can prevent clinical disease, while the response to treatment is very limited once larval invasion of the brain has occurred and neurological symptoms have developed (4). Albendazole is a relatively safe medication with few side effects or contraindications. Given the potential severity of infection following accidental ingestion of raccoon feces, prompt administration of a prophylactic course of albendazole should be considered $(4,12)$. The decision to provide prophylaxis should not require the identification of $B$ procyonis eggs in the environment.

Increasing awareness of the risk posed by raccoon feces and contact with raccoon latrines is critical in preventing this serious central nervous system infection. Preventive measures can minimize the risk that children may be exposed to $B$ procyonis in the backyards of our cities and towns. Equally important is a high index of suspicion on the part of physicians, who should consider the diagnosis, be aware of the implications of eosinophilia and elicit a history of raccoon exposure in all cases of encephalitis. Empirical therapy with albendazole and steroids should be started based on this suspicion, and not be delayed while waiting serological or other testing, to limit the damage by this life-threatening parasite.

ACKNOWLEDGEMENTS: We thank Jennifer Robichaud for performing the $B$ procyonis ELISA and Don Martin for identifying $B$ procyonis eggs from environmental samples.

\section{REFERENCES}

1. Rosatte RC. Management of raccoons (Procyon lotor) in Ontario, Canada: Do human intervention and disease have significant impact on raccoon populations? Mammalia 2000;64:369-90.

2. Kazacos KR. Baylisascaris procyonis and related species. In: Samuel WM, Pybus MJ, Kocan AA, eds. Parasitic Diseases of Wild Mammals, 2nd edn. Iowa State University Press, Ames, Iowa, 2001:301-41.

3. Weese JS, Peregrine AS, Armstrong J. Occupational health and safety in small animal veterinary practice: Part II - Parasitic zoonotic diseases. Can Vet J 2002;43:799-802.

4. Gavin PJ, Kazacos KR, Shulman ST. Baylisascariasis. Clin Microbiol Rev 2005;18:703-18.

5. Rowley HA, Uht RM, Kazacos KR, et al. Radiologic-pathologic findings in raccoon roundworm (Baylisascaris procyonis) encephalitis. Am J Neuroradiol 2000;21:415-20.

6. Moertel CL, Kazacos KR, Butterfield JH, Kita H, Watterson J, Gleich GJ. Eosinophil-associated inflammation and elaboration of eosinophil-derived proteins in 2 children with raccoon roundworm (Baylisascaris procyonis) encephalitis. Pediatrics 2001;108(5). <www. pediatrics.org/cgi/content/full/108/5/e93> (Version current at September 28, 2009).

7. Pai PJ, Blackburn BG, Kazacos KR, Warrier RP, Bégué RE. Full recovery from Baylisascaris procyonis eosinophilic meningitis. Emerg Infect Dis 2007;13:928-30.

8. Mets MB, Noble AG, Basti S, et al. Eye findings of diffuse unilateral subacute neuroretinitis and multiple choroidal infiltrates associated with neural larva migrans due to Baylisascaris procyonis. Am J Ophthalmol 2003;135:888-90. 
9. Yuen VH, Chang TS, Hooper PL. Diffuse unilateral subacute neuroretinitis syndrome in Canada. Arch Ophthalmol 1996;114:1279-82.

10. de Souza EC, Abujamra S, Nakashima Y, Gass JD. Diffuse bilateral subacute neuroretinitis: First patient with documented nematodes in both eyes. Arch Ophthalmol 1999;117:1349-51.
11. Lo Re V 3rd, Gluckman SJ. Eosinophilic meningitis. Am J Med. 2003;114:217-2.

12. American Academy of Pediatrics. Baylisascaris infections. In: Pickering LK, Baker CJ, Long SS, McMillan JA, eds. Red Book: 2006 Report of the Committee on Infectious Diseases, 27th edn. Elk Gross Village, IL: American Academy of Pediatrics, 2006:230-1. 


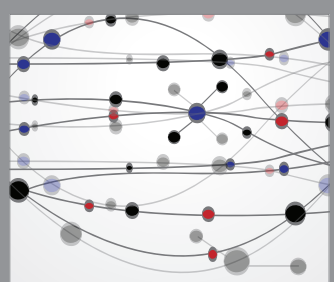

The Scientific World Journal
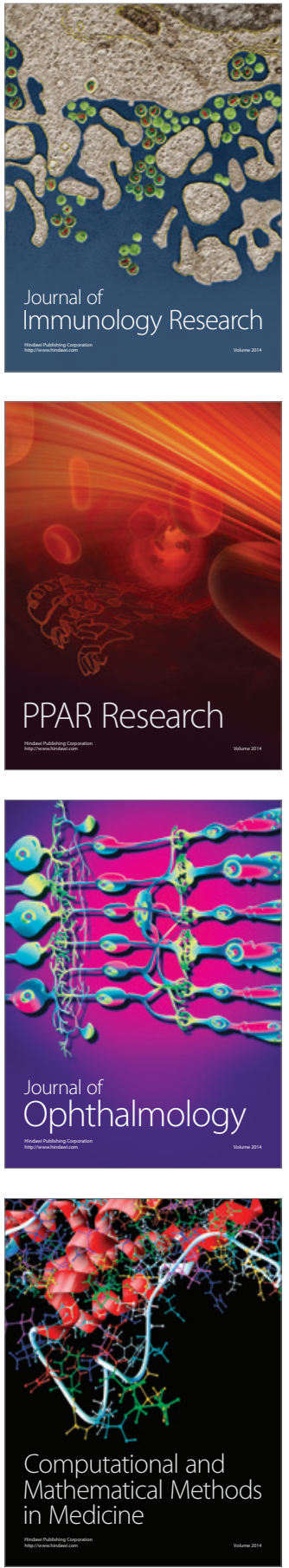

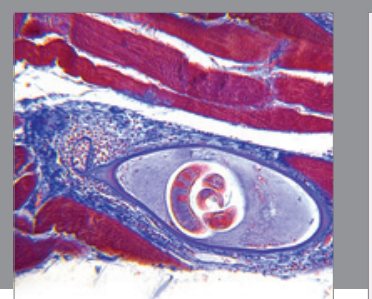

Gastroenterology Research and Practice

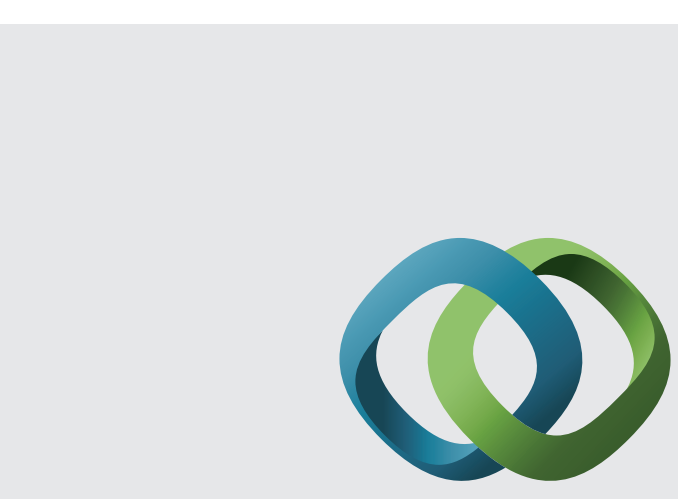

\section{Hindawi}

Submit your manuscripts at

http://www.hindawi.com
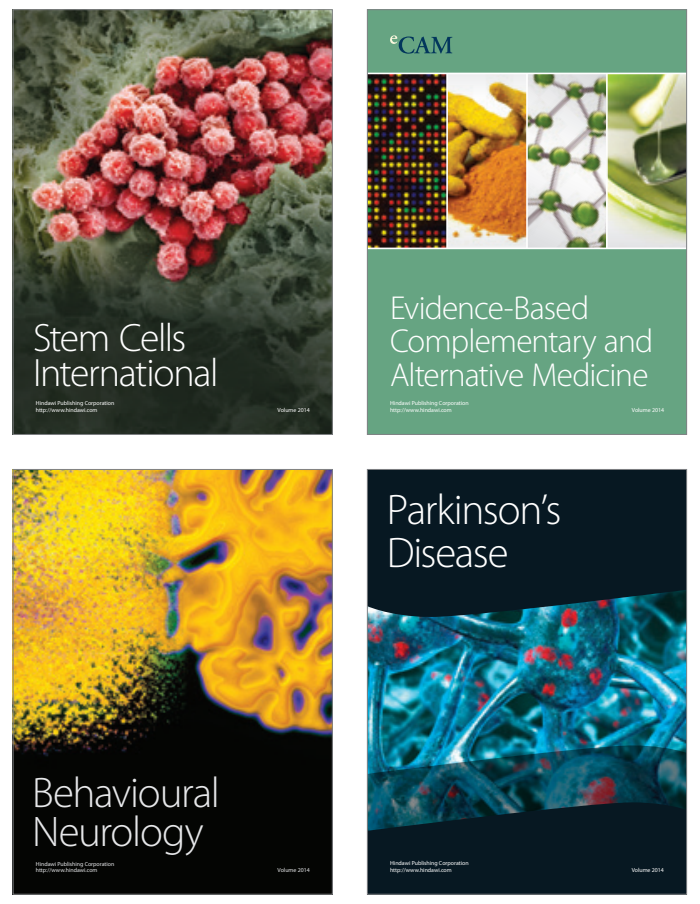
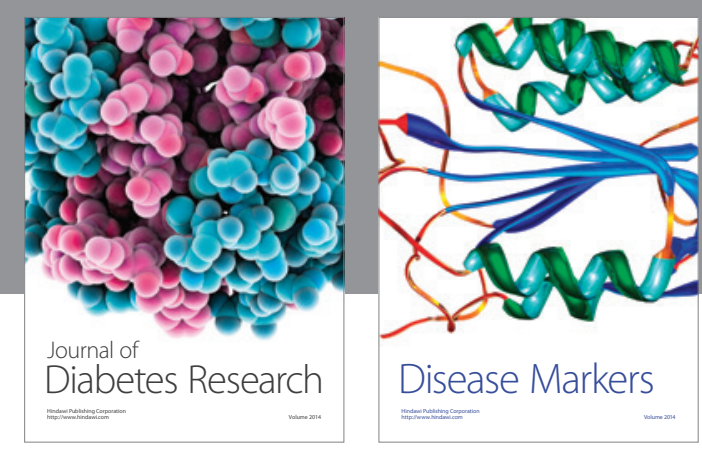

Disease Markers
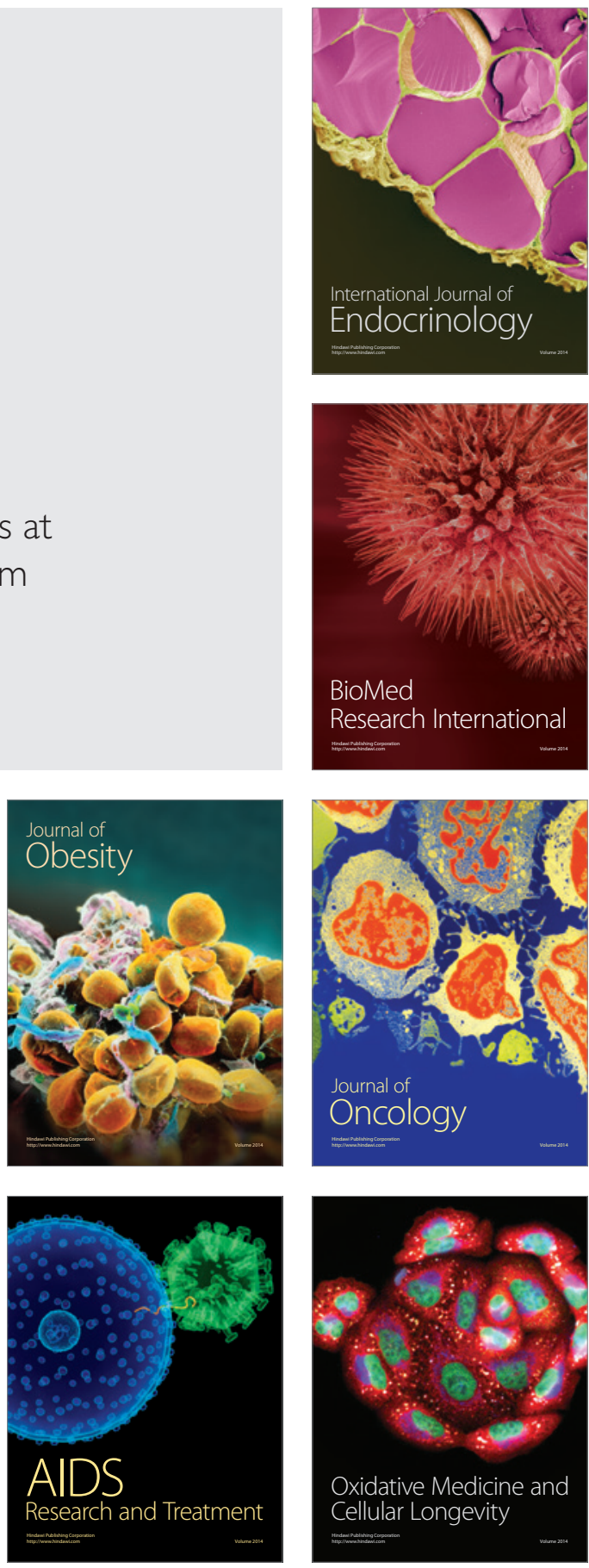